\title{
AMNESTIA ROMANA ROMKOWSKIEGO. UDZIA POMOCNIKA MINISTRA BEZPIECZEŃSTWA PUBLICZNEGO W PRZYGOTOWANIU, PRZEPROWADZENIU I OCENIE AKCJI AMNESTYJNEJ Z 1947 ROKU
}

\author{
Radosław Kurek (iD http://orcid.org/0000-0002-6764-7824 \\ Instytut Pamięci Narodowej
}

\author{
ABSTRACT \\ ROMAN ROMKOWSKI'S AMNESTY: THE ROLE OF AN ASSISTANT \\ TO THE MINISTER OF PUBLIC SECURITY IN THE PREPARATION, \\ EXECUTION AND EVALUATION OF THE 1947 AMNESTY
}

The article presents the significant influence of Colonel Roman Romkowski (an assistant to the minister in the Ministry of Public Security) on the organization and course of the amnesty, which was announced in Poland shortly after the elections in 1947. The hidden purpose of the amnesty was elimination of the independence underground, the greatest enemy of the communists in Poland. In order to accomplish this task, Romkowski had to implement special working methods in the public security services. They made it possible to obtain information on a large number of exposed underground soldiers and subject them to strict invigilation by the security service. Despite Romkowski's critical assessment of the final results of the amnesty, it was considered a great success.

Keywords: amnesty, public security services, Communism, independence underground, Poland after the World War II.

Słowa kluczowe: amnestia, aparat bezpieczeństwa publicznego, komunizm, podziemie niepodległościowe, Polska po II wojnie światowej. 
Pan Romkowski powiedziat wówczas do mnie:

„Dziwię się, że pan stawia takie warunki.

Ja jestem twórca ustawy amnestyjnej i uważam, że jest wielkim dobrodziejstwem".

Władysław Siła-Nowicki

Sfałszowane zwycięstwo komunistów w wyborach parlamentarnych z 19 stycznia 1947 roku było wyraźnym sygnałem dla społeczeństwa polskiego, że wszelkie nadzieje obliczone na rzeczywistą demokratyzację życia politycznego w kraju były jedynie ułudą. Rosnąca obojętność świata zachodniego na kierunek przemian zachodzących nad Wisłą zdawała się tylko potwierdzać tak postawioną tezę. Stawało się jasne, że na arenie międzynarodowej sprawa Polski została ostatecznie rozstrzygnięta po myśli Józefa Stalina.

Podziemie niepodległościowe, które w ostatnim czasie zostało zdziesiątkowane i rozproszone, wciąż stanowiło jednak pewne zagrożenie. W związku z tym komuniści, wykorzystując podniosły charakter zachodzących wydarzeń politycznych, a także postępujące zmęczenie społeczeństwa, raz jeszcze postanowili sięgnąć po dobrze znane im narzędzie w postaci amnestii. To, co dla nowej władzy było zaledwie politycznym aktem dobrej woli, dla aparatu bezpieczeństwa publicznego stanowiło dogodną okazję do podjęcia strategicznej rozgrywki mającej na celu rozpracowanie podziemia, objęcie jego członków ścisłą kontrolą i wreszcie przeprowadzenie likwidacji jego najgłębiej zakonspirowanych ogniw.

Tak rozumiany sens amnestii nie był niczym nowym. Doświadczenia akcji ujawnieniowej przeprowadzonej w 1945 roku dobitnie wykazały jednak, że w swojej masie organom bezpieczeństwa bardzo trudno przychodziło prowadzenie długofalowej, taktycznej rozgrywki przeciwko podziemiu. Jak wspominał Józef Światło, „Coraz to ktoś z ujawnionych lub powracających znajdował się za kratkami. Gorliwość ta była bardzo nie na rękę klice Bieruta, która liczyła na dalszy połów ludzi z podziemia i zagranicy"2. W strukturach resortu bezpieczeństwa jednym z największych krytyków takiego stanu rzeczy stał się ówczesny szef Departamentu I MBP (kontrwywiadowczego), a następnie pomocnik ministra bezpieczeństwa publicznego, Roman Romkowski ${ }^{3}$.

${ }^{1}$ IPN BU 2503/1, t. 4, Akta w sprawie karnej Władysława Nowickiego i in., k. 105.

${ }^{2}$ Z. Błażyński, Mówi Józef Światto. Za kulisami bezpieki i partii 1940-1950, Warszawa 2003, s. 125 .

${ }^{3}$ Roman Romkowski (właśc. Menasche Grünspan) urodził się 16 II 1907 r. w Krakowie. Od wczesnej młodości był związany z ruchem komunistycznym, najpierw jako działacz Związku Młodzieży Komunistycznej w Polsce (ZMK), a następnie Komunistycznej Partii Polski (KPP). W 1930 r. wyjechał do ZSRS, gdzie uczył się w Komunistycznym Uniwersytecie Mniejszości Narodowościowych Zachodu (KUMNZ), a następnie w Międzynarodowej Szkole Leninowskiej (tzw. Leninówce). Po powrocie do kraju został aresztowany i skazany za działalność komunistyczną. W czasie II wojny światowej przebywał na terenie Brześcia, a następnie działał w sowieckiej partyzantce na Kresach Wschodnich II Rzeczypospolitej. Od VII 1944 r. pełnił funkcję szefa Wydziału Operacyjnego (kontrwywiadowczego) w Resorcie Bezpieczeństwa Publicznego (RBP) Polskiego Komitetu Wyzwolenia Narodowego (PKWN), przekształconego w I 1945 r. w Departament I Ministerstwa Bezpieczeństwa Publicznego (MBP). 15 I 1946 r. powierzono mu funkcję pomocnika ministra bezpieczeństwa publicznego, a 10 I 1949 r. został mianowany 
Od samego początku był on bardzo mocno zaangażowany w organizację i przebieg pierwszej powojennej amnestii. Między innymi uczestniczył w rozmowach ze Stefanem Korbońskim, których głównym celem miało być nakłonienie byłego p.o. Delegata Rządu na Kraj do wydania odezwy wzywającej działaczy podziemia do ujawnienia się ${ }^{4}$. O ile zabiegi te nie przyniosły pożądanego rezultatu, o tyle próby pozyskania do współpracy byłego komendanta Obszaru Centralnego Delegatury Sił Zbrojnych (dalej: DSZ), ppłk. Jana Mazurkiewicza „Radosława”, zakończyły się już pełnym sukcesem. Z późniejszych zeznań Mazurkiewicza wynika, że to właśnie z Romkowskim konsultował większość swoich inicjatyw mających na celu ułatwienie powrotu członkom konspiracji do normalnego życia. Niestety bardzo szybko przekonał się, że większość obietnic dawanych mu przez szefa kontrwywiadu MBP była zwodnicza ${ }^{5}$ Z punktu widzenia Romkowskiego wcale nie chodziło bowiem o udzielanie realnej pomocy ujawnionym członkom podziemia:

wiceministrem bezpieczeństwa publicznego. Od XII 1948 r., nieprzerwanie aż do I 1955 r., zasiadał w Komitecie Centralnym (KC) Polskiej Zjednoczonej Partii Robotniczej (PZPR). Był odpowiedzialny m.in. za rozprawę z podziemiem niepodległościowym, walkę z tzw. prowokacją wewnątrzpartyjną oraz za represje wobec Kościoła katolickiego. Za popełnione zbrodnie 11 XI 1957 r. został skazany wyrokiem Sądu Wojewódzkiego m.st. Warszawy na 15 lat pozbawienia wolności. Z więzienia został zwolniony już w 1964 r. Zmarł 12 VII 1968 r. w Warszawie. Zob. L.T. Szmidt, Roman Romkowski [w:] Polski Slownik Biograficzny, t. XXXII, Kraków 1989, s. 2-4; H. Dominiczak, Organy bezpieczeństwa PRL 1944-1990. Rozwój i działalność w świetle dokumentów MSW, Warszawa 1997, s. 18; R. Kurek, Kaci bezpieki na tle Marca '68. Roman Romkowski, Anatol Fejgin i Józef Różański w oczach SB (1964-1968), „Aparat Represji w Polsce Ludowej 1944-1989” 2012, nr 1(10), s. 237-238; idem, Poczatki kariery krakowskiego komunisty na przykładzie losów Menaschego Grünspana (Romana Romkowskiego) w latach 1907-1930, „Prace Historyczne” 2016, nr 143, z. 1, s. 127-147.

${ }^{4}$ S. Korboński, W imieniu Rzeczypospolitej..., Warszawa 1991, s. 411-418.

5 Jak zeznawał po latach Mazurkiewicz: „Niestety organa bezpieczeństwa ówczesne, z ministrem Radkiewiczem na czele i z jego pomocnikiem Romkowskim i całym aparatem bezpieczeństwa nie poszły po tej linii i z miejsca zaczęło się łamanie tego przyrzeczenia, łamanie w ten sposób, że mimo obietnic ministra Radkiewicza i płk. Romkowskiego, że będą zwolnieni wszyscy przebywający w więzieniu, część tych ludzi nie została zwolniona, przede wszystkim odnosiło się to do obszaru lubelskiego, gdzie cały sztab okręgu lubelskiego siedział w więzieniu, ja kilkakrotnie interweniowałem w tej sprawie, płk Romkowski obiecywał, że to lada dzień się załatwi, sprawa przeciągnęła się od września aż do lutego. Już w tym czasie na terenie Lubelszczyzny ujawnienie dawno było skończone, kiedy dopiero zwolniono po długich staraniach sztab okręgu lubelskiego. Taka sama sprawa miała miejsce i na terenie Pomorza, okręg morsko-pomorski tak zwany AK chciał się ujawnić. Ja z tym zgłosiłem się do płk. Romkowskiego. On obiecał, że przebywający w tym czasie w więzieniu dowódca tego okręgu będzie natychmiast zwolniony. Ja wysłałem innego delegata na ten teren, ujawnienie zostało przeprowadzone, niestety płk Romkowski swojego przyrzeczenia nie dotrzymał, dowódca okręgu został oddany pod sąd, skazany i sprawa poszła dalej normalnym trybem". IPN BU 2548/29, Akta w sprawie karnej przeciwko Romanowi Romkowskiemu i in., Protokół rozprawy z dn. 8 X 1957 r. w sprawie karnej przeciwko Romanowi Romkowskiemu i in., k. 47-48. Podobnych interwencji Jana Mazurkiewicza skierowanych bezpośrednio pod adresem pomocnika ministra było znacznie więcej. Zazwyczaj kończyły się one jednoznacznie negatywną odpowiedzią, podobną do tej, jaką wystosował Romkowski w związku z prośbą o zwolnienie z więzienia Mirosława Ostromęckiego ps. „Majewski”: „Wymieniony jest znaczniejszym funkcyjnym NSZ i śledztwo będzie prowadzone", Cyt. za: T. Łabuszew ski, Amnestia 1945 r. i deklaracja Jana Mazurkiewicza „Radosława” [w:] Komunistyczne amnestie lat 1945-1947 - drogi do ,legalizacji”, czy zagłady?, red. W.J. Muszyński, Warszawa 2012, s. 126. 
„Był to świadomy i zbrodniczy plan - relacjonował po latach Józef Światło. - Celów jego nie ukrywano na tajnych konferencjach w bezpiece i partii. W 1946 r. brałem udział w specjalnej odprawie u pierwszego wiceministra bezpieczeństwa, gen. Romkowskiego [wówczas pomocnika ministra i pułkownika - RK]. Na odprawie tej Romkowski podkreślił, że przedwczesne aresztowania częściowo ujawnionych jednostek mogą tylko zaszkodzić akcji. Trzeba poczekać aż się Armia Krajowa w pełni ujawni i wtedy dopiero będzie można przeprowadzić całkowitą likwidację .

Amnestia miała służyć wciągnięciu strony niepodległościowej do gry, której zasady od początku do końca dyktowali komuniści. To właśnie temu celowi służyły zarówno rozmowy Romkowskiego z Korbońskim, współpraca z Mazurkiewiczem, jak i nieco późniejsze próby pozyskania przez niego byłego pracownika Oddziału VI (Informacji i Propagandy) DSZ Władysława Bartoszewskiego ${ }^{7}$ czy też byłego szefa sztabu Obszaru Zachodniego DSZ Kazimierza Leskiego ${ }^{8}$. Szef kontrwywiadu MBP instrumentalnie traktował również takie przedsięwzięcia jak akcja pomocowa dla ujawniających się żołnierzy, zainicjowana przez Mazurkiewicza:

Akcję pomocy, którą Kom[misje] Likw[idacyjne] mają organizować, należy ująć pod swoją kontrolę, tak by ujawniający się członkowie b[yłej] AK czuli, że opiekuje się nimi aparat Bezpieczeństwa i że Komisje Likwidacyjne udzielają pomocy tylko dzięki aparatowi Bezpieczeństwa. B[yłych] Akowców należy kierować do pracy planowo i rozmieszczać w ten sposób, by nie dopuścić do większego skupienia ich i by w swej pracy zawodowej byli pod odpowiednią kontrolą .

15 października 1945 roku, a więc w dniu formalnego zakończenia akcji amnestyjnej, Romkowski wydał rozkaz o przystąpieniu do bezwzględnej likwidacji oddziałów podziemia niepodległościowego, które zdecydowały się pozostać w konspiracji ${ }^{10}$. Dwa dni później zarządził natychmiastowe przesłanie do Departamentu I MBP list zawierających imienny spis osób zarejestrowanych przez Komisje Likwidacyjne, wraz z wykazem ich stopni oraz funkcji piastowanych podczas okupacji niemieckiej i tuż przed ujawnieniem się. Ponadto zobowiązywał on terenowe struktury organów bezpieczeństwa do przesłania sprawozdań o stanie agentury pozyskanej pośród byłych żołnierzy i działaczy AK-DSZ-WiN, a także do zabezpieczenia na potrzeby

${ }^{6}$ Z. Błażyński, op. cit., s. 117-118.

${ }^{7}$ W. Bartoszewski, Środowisko naturalne. Korzenie, Warszawa 2010, s. 250-251; zob. też: idem, Życie trudne, lecz nie nudne. Ze wspomnień Polaka w XX wieku, Kraków 2010, s. 202-203.

${ }^{8} \mathrm{~K}$. Leski, Życie niewłaściwie urozmaicone. Wspomnienia oficera wywiadu i kontrwywiadu AK, Warszawa 1989, s. 422-423; M. Roszkowski, Kazimierz Leski „Bradl”. Życie dobrze spetnione, Warszawa 2010, s. 259-260; zob. też: R. Terlecki, Dyktatura zdrady. Polska w 1947 roku, Kraków 1991, s. 22.

9 Cyt. za: Z. Nawrocki, Zamiast wolności. UB na Rzeszowszczyźnie 1944-1949, Rzeszów 1998, s. 137.

${ }^{10}$ Rok pierwszy. Powstanie i działalność aparatu bezpieczeństwa publicznego na Pomorzu i Kujawach (luty-grudzień 1945), red. B. Binaszewska, P. Rybarczyk, Warszawa-Bydgoszcz-Gdańsk 2010, s. 328-329; A.G. Kister, Studium zniewalania. Walka aparatu bezpieczeństwa z polskim zbrojnym podziemiem niepodległościowym na Lubelszczyźnie (1944-1947), Kraków 2005, s. 117. 
aparatu bezpieczeństwa wszelkiej dokumentacji wytworzonej przez Komisje Likwidacyjne (m.in. książek rejestracyjnych i arkuszy ewidencyjnych $)^{11}$.

Podczas odprawy kierowników wojewódzkich urzędów bezpieczeństwa publicznego, odbywającej się w dniach 30 listopada-1 grudnia 1945 roku Romkowski daleki był jednak od pozytywnej oceny akcji likwidacyjnej. Podczas swojego wystąpienia przeważnie srodze utyskiwał na przebieg i rezultaty amnestii: a to na nieumiejętność pracy funkcjonariuszy bezpieczeństwa $\mathrm{z}$ agenturą, a to na małą liczbę zdanej broni, a to wreszcie na ignorancję swoich podwładnych $w$ terenie ${ }^{12}$. Bez wątpienia liczył nie tylko na lepsze skutki całej akcji, ale przede wszystkim na lepsze zrozumienie aparatu co do istoty prowadzonej rozgrywki. Już wkrótce jednak nadarzyła się dogodna okazja, aby poprawić metody pracy organów bezpieczeństwa publicznego na tym polu.

$* * *$

Inicjatywa przeprowadzenia drugiej amnestii wyszła bezpośrednio od kierownictwa Ministerstwa Bezpieczeństwa Publicznego - i to właśnie tam, już od stycznia 1947 roku, zaczęły powstawać pierwsze projekty zapisów ustawy amnestyjnej ${ }^{13}$. W celu nadania planom kierownictwa UB nieco bardziej demokratycznego sztafażu 18 lutego 1947 roku powołano specjalną komisję parlamentarną, która miała wypełnić rolę formalnego projektodawcy ustawy amnestyjnej ${ }^{14}$. Stefan Korboński, który był członkiem owej komisji z ramienia PSL, wspominał po latach, że jej obradom przewodniczył wprawdzie poseł Włodzimierz Sokorski, ale w rzeczywistości o wszystkim decydował Romkowski, występujący w komisji jako przedstawiciel Ministerstwa Bezpieczeństwa Publicznego: „Patrzyliśmy na siebie z ukosa, ja dziwiąc się niezwykłej sytuacji, w jakiej mnie życie postawiło. Półtora roku temu więzień, badany przez Romkowskiego, dzisiaj razem z nim uczestnik narady sejmowej”'15.

W dalszej części swoich wspomnień Korboński, z właściwą dla swojego pisarstwa swadą, opisał przebieg dyskusji nad wysuwanymi jednostronnie przez Romkowskiego propozycjami kolejnych zapisów ustawy. Jak twierdził, spotykały się one z zupełnie bezkrytycznym przyklaskiwaniem ze strony pozostałych członków komisji, a gdy tylko on sam wystąpił z propozycją znacznego rozszerzenia amnestii, to po sprzeciwie Romkowskiego miał zostać za nią gremialnie zbesztany:

${ }^{11}$ Z. Zblewski, Dwa dokumenty dotyczqce stosunku UB do akcji ujawniania członków AK w 1945 roku, „Zeszyty Historyczne WiN-u” 2002, nr 17, s. 251-252.

12 Aparat bezpieczeństwa w latach 1944-1956. Taktyka, strategia, metody (cz. I, lata 1945-1947), oprac. A. Paczkowski, Warszawa 1994, s. 34.

${ }^{13}$ IPN BU 1572/525, Dokumentacja Ministerstwa Bezpieczeństwa Publicznego (Gabinet Ministra) dot. projektu ustawy o amnestii z 1947 r., k. 54-94; P. Gasztold-Seń, Problemy Ministerstwa Bezpieczeństwa Publicznego w przygotowaniu i realizacji amnestii 1945 i $1947 \mathrm{r}$. [w:] Komunistyczne amnestie lat 1945-1947 - drogi do ,legalizacji” czy zagłady?, red. W.J. Muszyński, Warszawa 2012, s. 65-66.

${ }^{14}$ L. Pietrzak, Amnestia 1947 roku i jej wykonanie przez organa bezpieczeństwa [w:] Podziemie zbrojne na Lubelszczyźnie wobec dwóch totalitaryzmów 1939-1956, red. S. Poleszak, A. Puławski, Warszawa 2003, s. 58.

${ }_{15}$ S. Korboński, W imieniu Kremla..., Warszawa 1997, s. 263. 
Sprawa wyglądała źle, więc zrzuciwszy pychę z serca, podszedłem do Romkowskiego i poprosiłem go na bok. Tam, w dłuższej rozmowie udało mi się przekonać go, że nie wystarczy, jeśli karę śmierci zmieni się na dożywotnie więzienie i jeśli takich skazanych nie uważa za możliwe zwolnić od razu, to w każdym razie należy im dać taką szansę na przyszłość. Również po pewnym wahaniu zgodził się ze mną, że wykluczenie kogokolwiek w lesie spod amnestii będzie równoznaczne z pozostawieniem tam narybku pod dalszą partyzantkę. Gdy wróciliśmy do stołu obrad komisji i Romkowski oświadczył, że zmienia stanowisko i godzi się na zmianę kary śmierci na 15 lat więzienia zamiast na dożywotnie i na niewyłączanie kogokolwiek z podziemia spod amnestii, w poglądach członków komisji zaszła natychmiastowa zmiana. Jeden po drugim chwalili zaaprobowane przez Romkowskiego zmiany. Ba, nawet padło parę uprzejmych słów pod moim adresem ${ }^{16}$.

Jak dotąd nie natrafiłem na żadne materiały, które mogłyby podać w wątpliwość ten swoistego rodzaju sposób procedowania ustawy amnestyjnej przez komisję parlamentarną. Wypada zatem przyjąć, że Romkowski rzeczywiście dysponował dużą dowolnością przy konstruowaniu zapisów dokumentu, który lada chwila miał trafić pod obrady Sejmu. Co oczywiste, na tym etapie każda zmiana zaaprobowana przez pomocnika ministra mogła jeszcze zostać wycofana. Nic takiego jednak nie nastąpiło i już 22 lutego pod obrady Parlamentu trafił bardzo mocno zliberalizowany projekt ustawy amnestyjnej, który w wyniku dyskusji doczekał się zaledwie kilku kosmetycznych poprawek ${ }^{17}$.

Ustawa o amnestii weszła w życie z dniem ogłoszenia w Dzienniku Ustaw Rzeczypospolitej Polskiej, to jest 25 lutego 1947 roku, i miała obowiązywać przez okres dwóch miesięcy. W tym samym dniu w Ministerstwie Bezpieczeństwa Publicznego wydany został niezwykle ważny dokument autorstwa Romkowskiego zatytułowany: „Instrukcja operacyjna w sprawie ujawnienia się elementów bandyckich i członków nielegalnego podziemia politycznego w związku z Ustawą Amnestyjną". Zwraca uwagę fakt, że pomimo swojego czysto wykonawczego charakteru, dokument ten został opatrzony przez pomocnika ministra, zapewne na wzór samej ustawy, swoistego rodzaju uroczystym wstępem: „Ustawa Amnestyjna jest wyrazem siły i trwałości obecnego ustroju i ma za zadanie ułatwić zerwanie z dotychczasową antypaństwową działalnością obałamuconym członkom politycznego i zbrojnego podziemia"18. W jego oczach amnestia miała zatem stanowić integralną część doniosłego aktu

16 Ibidem, s. 263-264.

${ }^{17}$ Ostateczny tekst ustawy, przyjęty przez Sejm Rzeczypospolitej Polskiej zob. Bijace serce partii. Dzienniki Personalne Ministerstwa Bezpieczeństwa Publicznego, t. I (1945-1947), red. A.K. Kunert, R.E. Stolarski, Warszawa 2001, s. 616-620.

${ }^{18}$ IPN BU 1572/525, Instrukcja operacyjna Romana Romkowskiego w sprawie ujawnienia się elementów bandyckich i członków nielegalnego podziemia politycznego w związku z Ustawą Amnestyjną, k. 102-103; zob. też: Instrukcja operacyjna ministra Romana Romkowskiego dotyczaca zachowania sie funkcjonariuszy bezpieczeństwa publicznego w stosunku do ujawniających się członków podziemia niepodległościowego, Warszawa, 25 luty 1947 r. [w:] Komunistyczne amnestie lat 1945-1947 - drogi do „legalizacji” czy zagłady?, red. W.J. Muszyński, Warszawa 2012, s. 433. Dla porównania w ustawie o amnestii z 22 II 1947 r. uroczysty wstęp został zawarty w art. 1: „Celem upamiętnienia otwarcia Sejmu Ustawodawczego, wybranego z woli Narodu w dniu 19 stycznia 1947 r., i wyboru Prezydenta Rzeczypospolitej oraz celem umożliwienia wszystkim obywatelom wzięcia udziału w odbudowie Demokratycznej Polski Ludowej - udziela się sprawcom i uczestnikom przestępstw, popełnionych w kraju lub zagranicą 
polegającego na ostatecznym przejęciu władzy w Polsce przez komunistów i zapewne życzył sobie, aby o tym politycznym entourage'u nie zapominali bezpośredni wykonawcy ustawy z urzędów bezpieczeństwa publicznego na terenie całego kraju.

Ale dokument ten posiadał jeszcze jeden niezwykle charakterystyczny rys, który - zapewne nie bezwiednie - przemycił do niego Romkowski. A mianowicie było to bardzo częste odwoływanie się na jego łamach do tych wszystkich aspektów akcji ujawnieniowej, które w jego oczach były największą bolączką amnestii z 1945 roku. Na przykład pozyskiwanie agentury w trakcie realizacji założeń ustawy amnestyjnej miało być, według jego zaleceń, nieco bardziej odłożone w czasie:

Zabrania się werbować kogokolwiek z kontyngentu ujawniających się. W trakcie ujawnienia należy wytypować kandydatów odpowiednich dla późniejszego ich werbunku [...]. Niektórych spośród ujawniających się - którzy sami oferują swoją współpracę w dziele rozszerzania ujawniania - należy wykorzystywać, lecz wyłącznie po tej linii i bez formalnego werbowania ich. Osoby, które chcą ujawnić się, lecz boją się swych kolegów czy też pewnych ośrodków sprzeciwiających się akcji ujawniania należy wykorzystywać - bez formalnego zwerbowania - dla rozpracowania i likwidacji tych ośrodków ${ }^{19}$.

Bardzo ciekawie nakreślony został $\mathrm{w}$ instrukcji problem zwalniania $\mathrm{z}$ więzień osób podlegających amnestii. Brak konsekwencji w tym zakresie w 1945 roku był jednym z głównych powodów znaczącego wyhamowania ówczesnej akcji ujawnieniowej ${ }^{20}$. Tym razem Romkowski wyraźnie wskazywał, że: „Wydziały śledcze wspólnie z Wydziałami operacyjnymi przejrzą listy aresztowanych śledczych tak $\mathrm{w}$ aresztach, i w więzieniach i ustalą listę osób podlegających natychmiastowemu zwolnieniu [... $]^{\prime 21}$. Zwolnieniom tym miała jednak towarzyszyć swoistego rodzaju polityka, która w jego oczach miała doprowadzić do zwiększenia efektywności całej akcji amnestyjnej:

Należy wykorzystać Ustawę Amnestyjną jako „legendę” przy zwalnianiu osób przez nas zawerbowanych. Z kontyngentu aresztowanych śledczych należy zwolnić pewną ilość celem wykorzystania ich dla propagandy za ujawnieniem się. Należy stosować przez cały okres dwumiesięczny stopniowe zwalnianie $\mathrm{z}$ aresztów i więzień celem stałego wzmacniania nastrojów na korzyść ujawniania się 22 .

Jak pokazuje casus aresztowanego jeszcze w styczniu 1947 roku Mieczysława Janucika, szefa wywiadu Obwodu WiN Wysokie Mazowieckie, realizacja podobnych założeń nie pozostała jedynie w sferze pobożnych życzeń Romkowskiego. Za sprawą wstawiennictwa komendanta Okręgu WiN Białystok, kpt. Józefa Ochmana ps. „Orwid”, szybko uznano, że zastosowanie wobec Janucika przepisów amnestii może być korzystne dla akcji ujawniania się członków WiN na tym terenie. W związ$\mathrm{ku} \mathrm{z}$ tym wszczęte przeciwko niemu postępowanie zostało umorzone, po czym za

przed dniem 5 lutego 1947 r., amnestii na zasadach określonych w niniejszej ustawie”, Bijace serce partii..., s. 616.

19 IPN BU 1572/525, Instrukcja operacyjna Romana Romkowskiego..., k. 102.

${ }^{20}$ P. Gasztold-Seń, op. cit., s. 53-57; T. Łabuszewski, op. cit., s. 115-117.

${ }^{21}$ IPN BU 1572/525, Instrukcja operacyjna Romana Romkowskiego..., k. 102.

${ }^{22}$ Ibidem, k. 102-103. 
sprawą rozkazu Wojskowej Prokuratury Rejonowej z 5 kwietnia 1947 roku został on zwolniony z więzienia, by następnie, 24 kwietnia, mógł ujawnić się przed komisją amnestyjną w Wysokiem Mazowieckiem ${ }^{23}$.

Ponadto za duży krok w kierunku liberalizacji postępowania organów bezpieczeństwa państwa na czas trwania amnestii należy uznać punkt instrukcji mówiący, że: „W terenach objętych akcją ujawniania się zaprzestać operacji wojskowych i aresztowań dla ułatwienia ujawniania się $[\ldots]^{\prime 24}$. O ile taktyczny wymiar tej przejściowej liberalizacji nie został tu aż tak mocno wyartykułowany, o tyle w punkcie dotyczącym sposobów udzielania pomocy ujawnionym puenta Romkowskiego nie pozostawiała już większych wątpliwości co do celów, jakim ma owa pomoc służyć:

Szefowie WUBP i PUBP winni dopilnować przeprowadzenia szerokiej akcji pomocy ujawniającym się przez kierowanie ich do pracy, udzielanie zapomóg pieniężnych, odzieżowych i żywnościowych, udzielanej przez Komisję Opieki Społecznej w województwach i powiatach. Pomoc ta winna być udzielana bezpośrednio w lokalach Komisji [chodzi o komisje amnestyjne - RK] przy WUBP i PUBP, co powiąże bardziej ujawniających się z nami, umożliwi w niektórych wypadkach operacyjne wykorzystanie i oddali ujawniających się od wpływów reakcyjnych towarzystw filantropijnych ${ }^{25}$.

O fundamentalnym znaczeniu instrukcji Romkowskiego świadczy również fakt, że stała się ona podstawą konstruowania kolejnych aktów wykonawczych, które powstawały już na poziomie poszczególnych pionów organizacyjnych MBP. Na przykład w wydanej 20 marca 1947 roku przez Julię Brystygier (dyrektor Departamentu V MBP) instrukcji dla naczelników wydziałów V WUBP autorka bardzo mocno podkreśliła, iż, zgodnie z wcześniejszą instrukcją Romkowskiego, to dopiero po zakończeniu amnestii należy zacząć w pełni wykorzystywać wszystkie, uzyskane w ten sposób materiały w celu typowania kandydatów do werbunku². Inspirację $\mathrm{z}$ dokumentu pomocnika ministra bez wątpienia czerpał również Departament Więziennictwa MBP, który w treści swojej instrukcji przewidywał m.in. zorganizowanie specjalnej kampanii wśród więźniów podlegających amnestii, mającej za zadanie przygotować ich do „pracy twórczej w odbudowie kraju i uodpornienie ich przed próbami wciągnięcia z powrotem przez podziemie na rozdroża nielegalności" ${ }^{27}$.

Zbalansowanie działań bezpieki w tym zakresie nie było jednak, jak się zdaje, jedynym zamierzeniem Romkowskiego. Nie ulega wątpliwości, że ogromną rolę przywiązywał on także do recepcji akcji amnestyjnej nie tylko przez samo podziemie niepodległościowe, ale i przez całe społeczeństwo. Jeszcze tego samego dnia, to jest 25 lutego, na falach Polskiego Radia udzielił on wywiadu, podczas którego

${ }^{23}$ Konspiracja i opór społeczny w Polsce 1944-1956 [w:] Stownik biograficzny, t. II, red. J. Kurtyka et al., Kraków-Warszawa-Wrocław 2004, s. 171.

${ }^{24}$ IPN BU 1572/525, Instrukcja operacyjna Romana Romkowskiego..., k. 103.

${ }^{25}$ Ibidem.

${ }^{26}$ L. Pietrzak, Amnestia 1947 roku i jej wykonanie przez organa bezpieczeństwa [w:] Podziemie zbrojne na Lubelszczyźnie..., s. 61.

${ }^{27}$ Cyt. za: W. Janowski, Przebieg ujawniania członków podziemia zbrojnego w 1947 roku - na tle akcji rozładowywania lasów w latach 1944-1946 (w świetle zasobów AAN) [w:] Pamiętny rok 1947, red. M.E. Ożóg, Rzeszów 2001, s. 147-149. 
przedstawił niemal idylliczną wizję rozpoczynającej się właśnie amnestii. Niemal połowę swojego wystąpienia poświęcił przedstawieniu form pomocy, jaka będzie udzielana wszystkim, którzy zdecydują się na ujawnienie, podkreślając przy tym, że to właśnie z inicjatywy Ministerstwa Bezpieczeństwa Publicznego powstała Międzyministerialna Komisja Niesienia Pomocy Amnestionowanym, w której czynnik społeczny - jak się wyraził - jest reprezentowany przez Polski Czerwony Krzyż (PCK). Mało tego, na sam koniec bardzo wyraźnie podkreślił, że zaświadczenia wystawiane przy okazji skorzystania $\mathrm{z}$ amnestii nie tylko nie będą stanowić przeszkody, ale przeciwnie, będą pomocne w uzyskaniu pracy ${ }^{28}$.

Wszystkie obietnice, tak hojnie rzucane w eter przez Romkowskiego, miały trafić nie tylko na grunt coraz bardziej defetystycznych nastrojów w samym podziemiu, ale również do zmęczonego nieustającą walką społeczeństwa. Pomocnik ministra doskonale zdawał sobie sprawę, że podziemie niepodległościowe będzie trwać dopóty, dopóki będzie miało ono swoje zaplecze pośród osób niezaangażowanych bezpośrednio w działalność konspiracyjną. Apatia wywołana wynikiem styczniowych wyborów stała się zatem dogodną okazją, aby przeciągnąć społeczeństwo na swoją stronę, ukazując z jednej strony dobrą wolę organów władzy państwowej, a z drugiej bezsens kontynuowania jakiegokolwiek oporu.

Trudno odmówić Romkowskiemu dużego stopnia zaangażowania i pieczołowitości podczas przygotowania amnestii. Zapewne doskonale zdawał sobie jednak sprawę, że nawet najlepsza ustawa i najlepsze instrukcje wykonawcze nie zastąpią jego bieżącej kontroli nad praktycznym przeprowadzeniem akcji ujawnienia podziemia. Tym bardziej że problemy z prawidłowym zrozumieniem intencji kierownictwa MBP nie były udziałem tylko funkcjonariuszy aparatu bezpieczeństwa. Tak było na przykład w przypadku orzeczenia wydanego przez Wojskowy Sąd Rejonowy w Warszawie 2 kwietnia 1947 roku w sprawie utrzymania w mocy wyroku 10 lat więzienia dla cichociemnego i żołnierza Armii Krajowej ppłk. Stefana Ignaszaka. Dopiero poparty przez pomocnika ministra wniosek do Bolesława Bieruta o ponowne zastosowanie aktu łaski przyniósł skrócenie kary do, przewidzianych ustawą amnestyjną, pięciu lat więzienia ${ }^{29}$. Podobne przypadki trudno rozpatrywać w kontekście bezinteresownej

${ }^{28}$ IPN BU 1572/525, Wywiad udzielony przez rzecznika MBP płk. Romkowskiego w Polskim Radiu 25 II 1947 r., k. 118-120; P. Gasztold-Seń, op. cit., s. 69. Na czele Międzyministerialnego Komitetu Pomocy Amnestionowanym stała mjr Hanna Wierbłowska, pełniąca dotąd zaledwie funkcję starszego inspektora w Gabinecie Ministra Bezpieczeństwa Publicznego. Ponadto w skład Komitetu mieli wejść przedstawiciele Ministerstwa Pracy i Opieki Społecznej, Ministerstwa Administracji Publicznej, Mininisterstwa Ziem Odzyskanych, Ministerstwa Obrony Narodowej, Ministerstwa Aprowizacji i Ministerstwa Przemysłu. Dokładny zakres pomocy udzielanej przez Komitet został określony w instrukcji z dn. 26 II 1947 r. i obejmował m.in. maksymalną kwotę wypłacanej jednorazowo zapomogi pieniężnej czy też maksymalną liczbę dni, przez które Komitet miał zapewnić nocleg osobie, która skorzystała z amnestii. IPN BU 1572/525, Instrukcja w sprawie niesienia pomocy amnestionowanym więźniom i ujawnionym członkom organizacji podziemnych z 26 II 1947 r., k. 104-105.

${ }^{29}$ IPN BU 944/487, Akta w sprawie karnej przeciwko Stefanowi Ignaszakowi i in., k. 25 i n.; S. Ig naszak, Cichociemny w PRL [w:] Księga świadectw. Skazani na karę śmierci w czasach stalinowskich $i$ ich losy, red. K. Madej et al., Warszawa 2005, s. 186. W kontekście naprawiania błędów amnestii z 1945 r. warto wspomnieć, że 12 VI 1957 r. Zgromadzenie Sędziów Najwyższego Sądu Wojskowego orzekło, że w 1945 r. sąd pierwszej instancji niesłusznie postanowił, iż Stefana Ignaszaka nie obejmują 
liberalizacji postawy komunistów wobec swoich wrogów. Rzeczywiste znaczenie miało przede wszystkim doświadczenie poprzedniej amnestii, która w znacznej mierze została zahamowana właśnie za sprawą mnożących się informacji o przypadkach niezastosowania przepisów dekretu do osób przebywających w więzieniach ${ }^{30}$.

Prawdziwe intencje, które przyświecały Romkowskiemu w podobnych przypadkach, można prześledzić na przykładzie losów ppor. Edwarda Wasilewskiego ps. „Wichura”. Ten zaledwie 24-letni oficer, który zasłynął między innymi dowództwem nad akcją rozbicia Obozu Specjalnego NKWD w Rembertowie w maju 1945 roku, stał się jednym z żołnierzy podziemia niepodległościowego, którzy odzyskali wolność na podstawie zapisów ustawy amnestyjnej. Od tej pory został poddany wnikliwej i długotrwałej inwigilacji przez funkcjonariuszy UB, którzy jednocześnie zadbali o to, aby nigdzie nie mógł znaleźć stałego miejsca zatrudnienia. Postawiło go to w bardzo trudnej sytuacji życiowej, która bez wątpienia wpłynęła na jego decyzję o podjęciu współpracy z organami bezpieczeństwa publicznego w zamian za zapewnienie pracy w czasopiśmie „Wola Ludu”, a następnie w popularnym piśmie kobiecym „Przyjaciółka” ${ }^{\prime \prime}$.

W kontekście przyjęcia Wasilewskiego do drugiej z tych gazet warto przytoczyć krótki fragment z książki Stanisława Podemskiego Pitawal PRL-u:

Po amnestii zostaje wkrótce aresztowany [chodzi oczywiście o amnestię z 1945 roku - RK], siedzi miesiącami w Ministerstwie Bezpieczeństwa Publicznego na Koszykowej, ale spreparowanego procesu nikt mu nie wytacza. Władze mają inny cel. Znając jego doświadczenie w walkach partyzanckich, usiłują wyciągnąć z nielegalnie przetrzymywanego, co by zrobił, gdyby (jak one) prowadził wojnę z UPA. Edzio milczy albo zbywa ogólnikami pytania swojego rozmówcy wiceministra Romkowskiego, odpowiedzialnego za Służbę Bezpieczeństwa. Gdy wychodzi z aresztu, jest zwalniany z każdej kolejnej pracy pod byle pretekstem: reorganizacji, likwidacji stanowiska, lepszego odeń kandydata. Za piątym razem Edek zatelefonował z biura przepustek Ministerstwa Bezpieczeństwa do Romkowskiego. Sekretarka z początku odmówiła połączenia, ale powiedział zagadkowo: „Ze mną na pewno będzie rozmawiał” i za chwilę odezwał się dobrze mu znany głos. Edzio powiedział: „Generale, jeżeli nie dacie żyć, skrzyknę ludzi do lasu, a wiecie, że na mój apel przyjdą". Po krótkim milczeniu usłyszał: „Zgłoście się do Przyjaciółki na Wiejską, tam będziecie pracować”. I rzeczywiście pracował przez lata całe do swej przedwczesnej śmierci. Pisał stały felieton z serduszkiem w rogu i podpisywał go krótkim „Ewa” (skrót od nazwiska Wasilewski i imienia Edward) ${ }^{32}$.

Co oczywiste, powyższy fragment z punktu widzenia standardów pracy historycznej jest co najmniej bardzo luźną i przerysowaną wersją rzeczywistości, nie mówiąc już o tym, że zupełnie pomija on kwestię ceny, jaką przyszło zapłacić Wasilewskiemu

przepisy dekretu o amnestii z 2 VIII 1945 r., IPN BU 944/487, Akta w sprawie karnej przeciwko Stefanowi Ignaszakowi i in., k. 75-81.

${ }^{30}$ T. Łabuszewski, op. cit., s. 110-125; P. Gasztold-S eń, op. cit., s. 52-57.

${ }^{31}$ K. Krajewski, T. Łabuszewski, Bohater i antybohater: Edward Wasilewski ,Wichura”, http:// www.fundacjapamietamy.pl/images/artykuly/Wichura.pdf [dostęp: 13 VI 2018 r.]; zob. też: K. Krajew ski, T. Łabuszewski, J. Pawłowicz, Polskie podziemie niepodległościowe województwie warszawskim 1944-1956 [w:] Atlas polskiego podziemia niepodlegtościowego 1944-1956, Warszawa-Lublin 2007, s. 240, 244.

32 S. Podemski, Pitawal PRL-u, Warszawa 2006, s. 72. 
za otrzymanie nowej posady. Ale w tym miejscu jest on istotny z nieco innej przyczyny, a mianowicie z powodu przypisania Romkowskiemu wystarania się o posadę dla byłego członka podziemia niepodległościowego w zamian za współpracę z UB. Czy rzeczywiście, w szczególnych przypadkach, mógł on osobiście zajmować się takimi sprawami? Jednoznaczna odpowiedź na takie pytanie wydaje się prawie niemożliwa. Niemniej jednak istnieją przynajmniej dwie przesłanki, które pośrednio mogą wskazywać, że wersja Podemskiego niekoniecznie musi być - przynajmniej w tym zakresie - całkowitą fantasmagorią. Po pierwsze, Romkowski posiadał kilku dobrych znajomych w Radzie Nadzorczej Robotniczej Spółdzielni Wydawniczej „Prasa” (na czele z Leonem Kasmanem ${ }^{33}$ ), do której należała „Przyjaciółka” ${ }^{34}$. Bez wątpienia posiadał on zatem odpowiednie kanały, aby umieszczać tam swoich protegowanych. Zapewne nieprzypadkowo (i to po drugie) z tego też tytułu o posadę w „Przyjaciółce” w 1953 roku ubiegała się żona Romkowskiego - Eleonora, która kilka lat wcześniej zrezygnowała z pracy w aparacie bezpieczeństwa państwa z powodów zdrowotnych ${ }^{35}$.

Bez względu na to, ile prawdy, a ile fikcji znajduje się w relacji Podemskiego, nie ulega wątpliwości, że to właśnie o stosowanie podobnych metod działania chodziło pomocnikowi ministra, kiedy pisał on w swojej instrukcji o prowadzeniu akcji pomocowej i związywaniu przez nią ujawnionych żołnierzy podziemia z organami bezpieczeństwa państwa.

Kolejną słabostką akcji ujawnieniowej z 1945 roku, która została dobrze zapamiętana przez Romkowskiego, było praktyczne wykonanie założeń amnestii przez przedstawicieli terenowych organów aparatu bezpieczeństwa. $\mathrm{Z}$ reguły byli oni bardzo niechętnie nastawieni do jakichkolwiek ustępstw wobec przedstawicieli podziemia, a nierzadko najzwyczajniej w świecie nie rozumieli istoty subtelnej rozgrywki prowadzonej przez centralę ${ }^{36}$. Prawdopodobnie to właśnie w związku z takim podejściem w instrukcji jego autorstwa znalazło się bardzo wyraźne podkreślenie, że za

${ }^{33}$ Ich znajomość zaczęła się jeszcze w okresie międzywojennym, kiedy to m.in. Leon Kasman był nauczycielem Romkowskiego w Międzynarodowej Szkole Leninowskiej (tzw. Leninówce). Po wielu latach Romkowski w bardzo ciepłych słowach wspominał pomoc, jaką uzyskał wówczas od „Lolka”, w szczególności w studiowaniu zasad ekonomii, IPN BU 2548/44, Protokół rozprawy z dn. 6 XI 1957 r. w sprawie karnej przeciwko Romanowi Romkowskiemu i in., k. 62-63. W swoim życiorysie spisanym w 1948 r. wspominał zresztą, że z jego przedwojennej działalności najlepiej znają go Władysław Gomułka, Leon Kasman i Jan Izydorczyk, AAN, KC PZPR, CK 6242, Życiorys Romana Romkowskiego z 8 XII 1948 r. wraz z ankietą dla aktywu partyjnego PPR, k. 28. Ich losy stykały się jeszcze wielokrotnie, i to zarówno w trakcie II wojny światowej, jak i po jej zakończeniu. Nawet kiedy w 1957 r. postawiono Romkowskiego przed sądem za zbrodniczą działalność w aparacie bezpieczeństwa państwa, Kasman nie omieszkał wspomnieć podczas swoich zeznań, że ten cieszył się „bardzo dobrą sławą” w okresie swojej działalności w partyzantce sowieckiej, IPN BU 2548/35, Protokół rozprawy z dn. 18 X 1957 r. w sprawie karnej przeciwko Romanowi Romkowskiemu i in., k. 14.

${ }^{34}$ M. Polaczek-Bigaj, Robotnicza Spółdzielnia Wydawnicza ,Prasa-Książka-Ruch”. Studium powstania, działalności i likwidacji, Kraków 2016, s. 34.

35 IPN BU 0193/3933, Akta osobowe Eleonory Romkowskiej z d. Kempa, c. Władysława, k. 40-41.

${ }^{36}$ P. Gasztold-Seń, op. cit., s. 56-57, 63-64. 
rezultaty obecnej amnestii odpowiadać będą bezpośrednio szefowie wojewódzkich i powiatowych urzędów bezpieczeństwa publicznego ${ }^{37}$.

Niejednokrotnie zresztą Romkowski osobiście nadzorował przebieg akcji ujawnieniowej w terenie, a jego oczkiem w głowie bez wątpienia pozostawało województwo lubelskie. To właśnie tutaj prowadził najaktywniejsze rozmowy z przedstawicielami kierownictwa Okręgu Lublin WiN na temat warunków ujawnienia oddziałów podziemia niepodległościowego. 22 marca 1947 roku mógł świętować na tym polu odniesienie poważnego sukcesu, ponieważ w jego obecności ujawnił się między innymi dotychczasowy komendant Okręgu Lublin WiN, ppłk Wilhelm Szczepankie$w_{i c z}{ }^{38}$ oraz inspektor Inspektoratu Lublin tej organizacji, Władysław Siła-Nowicki ${ }^{39}$.

Nieco gorzej układały się natomiast rozmowy dotyczące warunków ujawnienia się samych oddziałów zbrojnych, a w szczególności ujawnienia żołnierzy pozostających pod dowództwem majora Hieronima Dekutowskiego ps. „Zapora”. Kilkakrotne spotkania Romkowskiego z Siłą-Nowickim, który kontaktował się w tej sprawie z „Zaporą”, doprowadziły do ujawnienia się zaledwie części jego ludzi. Dekutowski pozostawał nieufny wobec rzeczywistych intencji organów bezpieczeństwa, a Siłę-Nowickiego coraz bardziej podejrzewano o prowadzenie - jak po latach wyraził się o tym Romkowski - „akcji dwutorowej” ${ }^{40}$. W rezultacie po paru miesiącach były inspektor WiN postanowił podjąć wraz z Dekutowskim próbę przedostania się na Zachód. Jak się jednak okazało, całe przedsięwzięcie od początku pozostawało pod ścisłą kontrolą organów bezpieczeństwa państwa, a jedna z informatorek UB o pseudonimie „Lena” (później ps. „Maria”) była nawet prowadzona bezpośrednio przez Romkowskiego. W rezultacie próba ucieczki zakończyła się ich aresztowaniem tuż po przybyciu na punkt przerzutowy umiejscowiony w Nysie na Opolszczyźnie ${ }^{41}$.

Do innych województw Romkowski wysyłał swoich zaufanych podwładnych. Tak było na przykład w przypadku Henryka Wendrowskiego, który po wielu latach wspominał, że akcją amnestyjną w województwie białostockim kierował właśnie $\mathrm{z}$ jego poruczenia. Romkowski miał być zresztą bardzo zadowolony z rezultatów jego pracy na tym terenie, a szczególnie pozytywne wrażenie wywarły na nim wyniki rozmów, jakie Wendrowski podjął z komendantem Okręgu WiN Białystok, kpt. Józefem Ochmanem, który jakoby w ich wyniku doprowadził do ujawnienia całości podległych sobie struktur: „Z lasu wyszło około półtora tysiąca ludzi - twierdził Wendrowski - Romkowskiemu się to spodobało. Kazał sprawę prowadzić dalej.

${ }^{37}$ IPN BU 1572/525, Instrukcja operacyjna Romana Romkowskiego..., k. 103.

${ }^{38}$ Konspiracja i opór społeczny w Polsce 1944-1956. Stownik biograficzny, t. I, red. J. Kurtyka et al., Kraków-Warszawa-Wrocław 2002, s. 435.

${ }^{39}$ IPN BU 2503/1, t. 4, Akta w sprawie karnej Władysława Nowickiego i in., k. 103.

${ }^{40}$ Ibidem, k. 103-106.

${ }^{41}$ A. Zagórski, Siła-Nowicki Władysław, „Zeszyty Historyczne WiN-u” 1996, nr 9, s. 235; T. Ba1bus, O Polskę Wolna i Niezawisła (1945-1948). WiN w poludniowo-zachodniej Polsce (geneza-struktury - działalność - likwidacja - represje), Kraków-Wrocław 2004, s. 181-183; Z. Woźniczka, Zrzeszenie , Wolność i Niezawistośc”" 1945-1952, Warszawa 1992, s. 199-200; P. Bukalska, Krwawa Luna, Warszawa 2016, s. 168-171; zob. też: H. Piecuch, Od Bieruta do Ochaba. Akcje specjalne, Warszawa 1996, s. 123. 
Dostałem do pomocy masę osób" ${ }^{\text {‘2 }}$. Wszystko wskazuje na to, że jego relacja w tym zakresie nie była znacząco przesadzona, skoro na jednej z odpraw szefostwa aparatu bezpieczeństwa publicznego, odbywającej się tuż po zakończeniu amnestii, pomocnik ministra otwarcie oświadczył, że zadowalające wyniki akcja ujawnieniowa przyniosła jedynie w dwóch województwach: lubelskim i białostockim ${ }^{43}$.

Właściwe podsumowanie i ocena działań aparatu bezpieczeństwa państwa związanych z realizacją ustawy amnestyjnej odbyła się 28 kwietnia 1947 roku podczas odprawy szefów wojewódzkich urzędów bezpieczeństwa publicznego, a zatem zaledwie trzy dni po formalnym zakończeniu akcji ujawnieniowej ${ }^{44}$ i dokładnie dwa tygodnie po Plenum KC PPR, podczas którego zostały nakreślone nowe założenia do polityki komunistów w warunkach niedawnego zwycięstwa wyborczego ${ }^{45}$. Już w pierwszych zdaniach wypowiedzianych przez Romkowskiego dawało się wyraźnie odczuć jego duże niezadowolenie co do skutków, jakie ona przyniosła. Nie sposób jednak nie odnieść przy tym wrażenia, że swoją ogólną ocenę amnestii oparł on na dość hermetycznym twierdzeniu, jakoby rezultaty akcji amnestyjnej były wprost proporcjonalne do intensywności, z jaką wcześniej na danym terenie prowadzono akcje pacyfikacyjne. Według niego to właśnie one miały doprowadzić w niektórych częściach kraju do takiego rozbicia podziemia, że skorzystanie z amnestii de facto stało się dla wielu osób jedynym rozsądnym rozwiązaniem ${ }^{46}$.

Być może tak sztywne stanowisko pomocnika ministra wynikało bezpośrednio z tego, o czym powiedział nieco później. Uznał on bowiem, że największym błędem w czasie amnestii było wstrzymanie akcji likwidacyjnej, dodając przy tym samokrytycznie, że co prawda: „Na początku dawaliśmy instrukcję, aby zaniechać prowadzenia wielkich operacji, by nie hamować wyjścia z podziemia, każdy jednak fakt napadu musiał być ścigany do końca i konsekwentnie”. Jak skonstatował: „Ta zasada była wykonana nie tak jak należy. Nie wszystkie akty terroru i nie wszystkie napady w czasie amnestii były ścigane tak jak należało"47. O wysokich wymaganiach, jakie miał w tym zakresie, świadczyło surowe upomnienie wszystkich słuchaczy, że kierownictwo MBP nie będzie przyjmować do wiadomości raportów ze śledztw w sprawie napadów, które przez wiele kolejnych miesięcy kończone są jednakowymi stwierdzeniami, iż „śledztwo trwa” lub „pościg trwa”. Romkowski żądał

${ }^{42}$ H. Piecuch, op. cit., s. 227-228; P. Łapiński, Amnestia 1947 roku na Białostocczyźnie, „Biuletyn Instytutu Pamięci Narodowej”, I-II 2008, nr 1-2 (84-85), s. 74; Ochman Józef [w:] Zrzeszenie „Wolność i Niezawistość” $w$ dokumentach, t. VI, cz. 3, oprac. A. Zagórski, Wrocław 2000, s. 484-485.

${ }^{43}$ Aparat bezpieczeństwa... (cz. I, lata 1945-1947), s. 104-105.

${ }^{44}$ Oficjalny komunikat MBP dopuszczał dodatkowe trzy dni na załatwienie wszystkich formalności związanych z zakończeniem amnestii, w związku z czym w wielu miejscach akcja ujawnieniowa przedłużyła się nawet o kilka dni, zob. P. Gasztold-Seń, op. cit., s. 79.

${ }_{45}$ Plenum KC PPR odbyło się w dniach 13-14 IV 1947 r. Zob. Archiwum Ruchu Robotniczego, red.

G. Iwański i. in., t. VII, Warszawa 1982, s. 199-203.

${ }^{46}$ Aparat bezpieczeństwa... (cz. I, lata 1945-1947), s. 104-105.

${ }^{47}$ Ibidem, s. 105. 
natychmiastowych efektów: „Te pościgi i śledztwa - grzmiał do zgromadzonych trwają bez końca, po dwa i trzy miesiące" 48 .

Za konieczne uznał również wprowadzenie pewnych istotnych korekt i uściśleń na płaszczyźnie kontroli osób ujawnionych. Jak twierdził, nie należy dopuszczać do sytuacji, w której mogło dochodzić do swobodnego kontaktu między osobami ujawnionymi i nieujawnionymi: „My musimy stworzyć pewną ścianę i odgrodzić ujawnionych od podziemia [...]". Po raz kolejny powołał się przy tym na doświadczenie pierwszej amnestii, kiedy to dopuszczenie do takich kontaktów doprowadzało niejednokrotnie do przypadków powrotu do współpracy z podziemiem. Co prawda w sporadycznych przypadkach dopuszczał on możliwość wykorzystywania ujawnionych do rozpracowania tej czy innej nielegalnej organizacji, ale, jak podkreślił, „główna nasza linia to odseparowanie ujawnionych od podziemia"49.

Obiektywnie rzecz ujmując, amnestia z 1947 roku okazała się sporym sukcesem aparatu bezpieczeństwa państwa. Tuż po jej zakończeniu jej rezultaty zachwalał w Sejmie minister Stanisław Radkiewicz ${ }^{50}$, a po wielu latach jego zadowolenie na tym polu było znacznie bardziej zrozumiałe dla historyków niż surowy krytycyzm Romkowskiego, który Andrzej Paczkowski uznał nawet za bezprzedmiotowy ${ }^{51}$. Był to jednak jeden z najbardziej charakterystycznych rysów jego podejścia do wszystkich zadań wykonywanych przez urzędy bezpieczeństwa publicznego. Od samego początku wyraźnie drażnił go brak elastyczności podległego mu aparatu i dostrzeganie przez niego wyłącznie celów na tak zwaną krótką metę. Nade wszystko domagał się pracy systematycznej i również przez pryzmat takiego postępowania za wszelką cenę chciał ukazać skutki amnestii. Niezmiennie żądał od funkcjonariuszy UB znacznie lepszej pracy w wymiarze jakościowym, a nie tylko ilościowym. Jak po latach zwykł o nim mawiać szef Departamentu Śledczego MBP, Józef Różański, „[...] nie był on dowódcą na niby, miał swoje zdecydowane zdanie i umiał narzucać poglądy"s2.

Pomimo niezwykle krytycznego stosunku do pracy aparatu bezpieczeństwa podczas amnestii jego osobisty wkład w walkę z podziemiem niepodległościowym został dostrzeżony. 22 lipca 1947 roku został awansowany do stopnia generała brygady oraz odznaczony Orderem Odrodzenia Polski III klasy za: „wybitne zasługi, wykazane męstwo $\mathrm{w}$ walce $\mathrm{z}$ bandami dywersyjnymi oraz wzorową służbę" ${ }^{3}$. Z czasem znacząco złagodził też swoją ocenę w zakresie skutków amnestii. Podczas odprawy kierownictwa aparatu bezpieczeństwa publicznego z października 1947 roku mówił

${ }^{48}$ Ibidem.

${ }^{49}$ Ibidem.

${ }^{50}$ P. Gasztold-Seń, op. cit., s. 79.

${ }_{51}$ A. Paczkowski, Aparat bezpieczeństwa w walce z podziemiem w Polsce w latach 1944-1956. Struktury organizacyjne i kierunki działań [w:] Aparat represji a opór spoleczeństwa wobec systemu komunistycznego w Polsce i na Litwie w latach 1944-1956, red. P. Niwiński, Warszawa 2005, s. 64-65; P. Gasztold-Seń, op. cit., s. 80-82.

${ }_{52}$ S. Marat, J. Snopkiewicz, Ludzie bezpieki. Dokumentacja czasu bezprawia, Warszawa 1990, s. 41 .

53 Bijące serce partii..., s. 163. 
już o nich w następujący sposób: „Byłoby niesłusznym twierdzić, że mamy wzrost oddziałów bandyckich, że cała nasza praca i życie polityczne i ekonomiczne w kraju mimo wszystko pokazują, że bandy istnieją i rosną, mimo olbrzymich likwidacji i akcji amnestyjnej, która się znacznie przyczyniła do likwidacji, że bandy mimo to rosną. Jest to niezgodne z prawdą, bandy nie rosną na ogół w kraju" ${ }^{54}$.

\section{BIBLIOGRAFIA}

\section{Źródła archiwalne}

Archiwum Akt Nowych w Warszawie

AAN, KC PZPR, CK 6242, Życiorys Romana Romkowskiego z 8 XII 1948 r. wraz z ankietą dla aktywu partyjnego PPR.

Archiwum Instytutu Pamięci Narodowej w Warszawie

IPN BU 0193/3933, Akta osobowe Eleonory Romkowskiej zd. Kempa, c. Władysława

IPN BU 944/487, Akta w sprawie karnej przeciwko Stefanowi Ignaszakowi i in.

IPN BU 1572/525, Dokumentacja Ministerstwa Bezpieczeństwa Publicznego (Gabinet Ministra) dot. projektu ustawy o amnestii z $1947 \mathrm{r}$.

IPN BU 2503/1, t. 4, Akta w sprawie karnej Władysława Nowickiego i in.

IPN BU 2548, Akta w sprawie karnej przeciwko Romanowi Romkowskiemu i in.

\section{Wydawnictwa źródłowe i opracowania}

Aparat bezpieczeństwa w latach 1944-1956. Taktyka, strategia, metody (cz. I, lata 19451947), oprac. A. Paczkowski, Warszawa 1994.

Archiwum Ruchu Robotniczego, red. G. Iwański i. in., t. VII, Warszawa 1982.

Balbus T., O Polske Wolna i Niezawista (1945-1948). WiN w poludniowo-zachodniej Polsce (geneza - struktury - działalność - likwidacja - represje), Kraków-Wrocław 2004.

Bartoszewski W., Środowisko naturalne. Korzenie, Warszawa 2010.

Bartoszewski W., Życie trudne, lecz nie nudne. Ze wspomnień Polaka w XX wieku, Kraków 2010.

Bijace serce partii. Dzienniki Personalne Ministerstwa Bezpieczeństwa Publicznego, t. I (1945-1947), red. A.K. Kunert, R.E. Stolarski, Warszawa 2001.

Błażyński Z., Mówi Józef Światto. Za kulisami bezpieki i partii 1940-1950, Warszawa 2003.

Bukalska P., Krwawa Luna, Warszawa 2016.

Dominiczak H., Organy bezpieczeństwa PRL 1944-1990. Rozwój i działalność w świetle dokumentów MSW, Warszawa 1997.

Gasztold-Seń P., Problemy Ministerstwa Bezpieczeństwa Publicznego w przygotowaniu i realizacji amnestii 1945 i 1947 r. [w:] Komunistyczne amnestie lat 1945-1947 - drogi do ,legalizacji” czy zagłady?, red. W.J. Muszyński, Warszawa 2012.

${ }^{54}$ Aparat bezpieczeństwa... (cz. I, lata 1945-1947), s. 193. 
Ignaszak S., Cichociemny w PRL [w:] Księga świadectw. Skazani na karę śmierci w czasach stalinowskich i ich losy, red. K. Madej et al., Warszawa 2005.

Instrukcja operacyjna ministra Romana Romkowskiego dotyczaca zachowania się funkcjonariuszy bezpieczeństwa publicznego w stosunku do ujawniajacych się członków podziemia niepodległościowego, Warszawa, 25 luty 1947 r. [w:] Komunistyczne amnestie lat 1945-1947 - drogi do ,, legalizacji” czy zagłady?, red. W.J. Muszyński, Warszawa 2012.

Janow ski W., Przebieg ujawniania członków podziemia zbrojnego w 1947 roku - na tle akcji rozładowywania lasów w latach 1944-1946 (w świetle zasobów AAN) [w:] Pamiętny rok 1947, red. M.E. Ożóg, Rzeszów 2001.

Kister A.G., Studium zniewalania. Walka aparatu bezpieczeństwa z polskim zbrojnym podziemiem niepodległościowym na Lubelszczyźnie (1944-1947), Kraków 2005.

Konspiracja i opór społeczny w Polsce 1944-1956. Stownik biograficzny, t. I, red. J. Kurtyka et al., Kraków-Warszawa-Wrocław 2002.

Konspiracja i opór społeczny w Polsce 1944-1956. Stownik biograficzny, t. II, red. J. Kurtyka et al., Kraków-Warszawa-Wrocław 2004.

Korboński S., W imieniu Kremla..., Warszawa 1997.

Korboński S., W imieniu Rzeczypospolitej..., Warszawa 1991.

Krajewski K., Łabuszewski T., Pawłowicz J., Polskie podziemie niepodległościowe województwie warszawskim 1944-1956 [w:] Atlas polskiego podziemia niepodległościowego 1944-1956, Warszawa-Lublin 2007.

Krajewski K., Łabuszewski T., Bohater i antybohater: Edward Wasilewski ,, Wichura”, http://www.fundacjapamietamy.pl/images/artykuly/Wichura.pdf [dostęp: 13.06.2018 r.].

Kurek R., Kaci bezpieki na tle Marca '68. Roman Romkowski, Anatol Fejgin i Józef Różański w oczach SB (1964-1968), „Aparat Represji w Polsce Ludowej 1944-1989” 2012, nr 1(10).

Kurek R., Początki kariery krakowskiego komunisty na przykładzie losów Menaschego Grünspana (Romana Romkowskiego) w latach 1907-1930, „Prace Historyczne” 2016, nr 143, z. 1.

Leski K., Życie niewłaściwie urozmaicone. Wspomnienia oficera wywiadu i kontrwywiadu $A K$, Warszawa 1989.

Łabuszewski T., Amnestia 1945 r. i deklaracja Jana Mazurkiewicza „Radosława” [w:] Komunistyczne amnestie lat 1945-1947 - drogi do ,legalizacji” czy zagłady?, red. W.J. Muszyński, Warszawa 2012.

Łapiński P., Amnestia 1947 roku na Białostocczyźnie, „Biuletyn Instytutu Pamięci Narodowej" styczeń-luty 2008, nr 1-2(84-85).

Marat S., Snopkiewicz J., Ludzie bezpieki. Dokumentacja czasu bezprawia, Warszawa 1990.

Nawrocki Z., Zamiast wolności. UB na Rzeszowszczyźnie 1944-1949, Rzeszów 1998.

Ochman Józef [w:] Zrzeszenie „Wolność i Niezawisłość” w dokumentach, t. VI, cz. 3, oprac. A. Zagórski, Wrocław 2000.

Paczkowski A., Aparat bezpieczeństwa $w$ walce z podziemiem $w$ Polsce $w$ latach 1944 1956. Struktury organizacyjne i kierunki dziatań [w:] Aparat represji a opór spoteczeństwa wobec systemu komunistycznego w Polsce i na Litwie w latach 1944-1956, red. P. Niwiński, Warszawa 2005.

Piecuch H., Od Bieruta do Ochaba. Akcje specjalne, Warszawa 1996.

Pietrzak L., Amnestia 1947 roku i jej wykonanie przez organa bezpieczeństwa [w:] Podziemie zbrojne na Lubelszczyźnie wobec dwóch totalitaryzmów 1939-1956, red. S. Poleszak, A. Puławski, Warszawa 2003.

Podemski S., Pitawal PRL-u, Warszawa 2006. 
Polaczek-Bigaj M., Robotnicza Spółdzielnia Wydawnicza „Prasa-Ksiażka-Ruch”. Studium powstania, działalności i likwidacji, Kraków 2016.

Rok pierwszy. Powstanie $i$ działalność aparatu bezpieczeństwa publicznego na Pomorzu i Kujawach (luty-grudzień 1945), red. B. Binaszewska, P. Rybarczyk, WarszawaBydgoszcz-Gdańsk 2010.

Roszkowski M., Kazimierz Leski „Bradl”. Życie dobrze spetnione, Warszawa 2010.

Szmidt L.T., Roman Romkowski [w:] Polski Słownik Biograficzny, t. XXXII, Kraków 1989. Terlecki R., Dyktatura zdrady. Polska w 1947 roku, Kraków 1991.

Woźniczka Z., Zrzeszenie ,Wolność i Niezawisłość” 1945-1952, Warszawa 1992. Zagórski A., Siła-Nowicki Władysław, „Zeszyty Historyczne WiN-u” 1996, nr 9.

Zblewski Z., Dwa dokumenty dotyczace stosunku UB do akcji ujawniania członków AK w 1945 roku, ,Zeszyty Historyczne WiN-u” 2002, nr 17. 